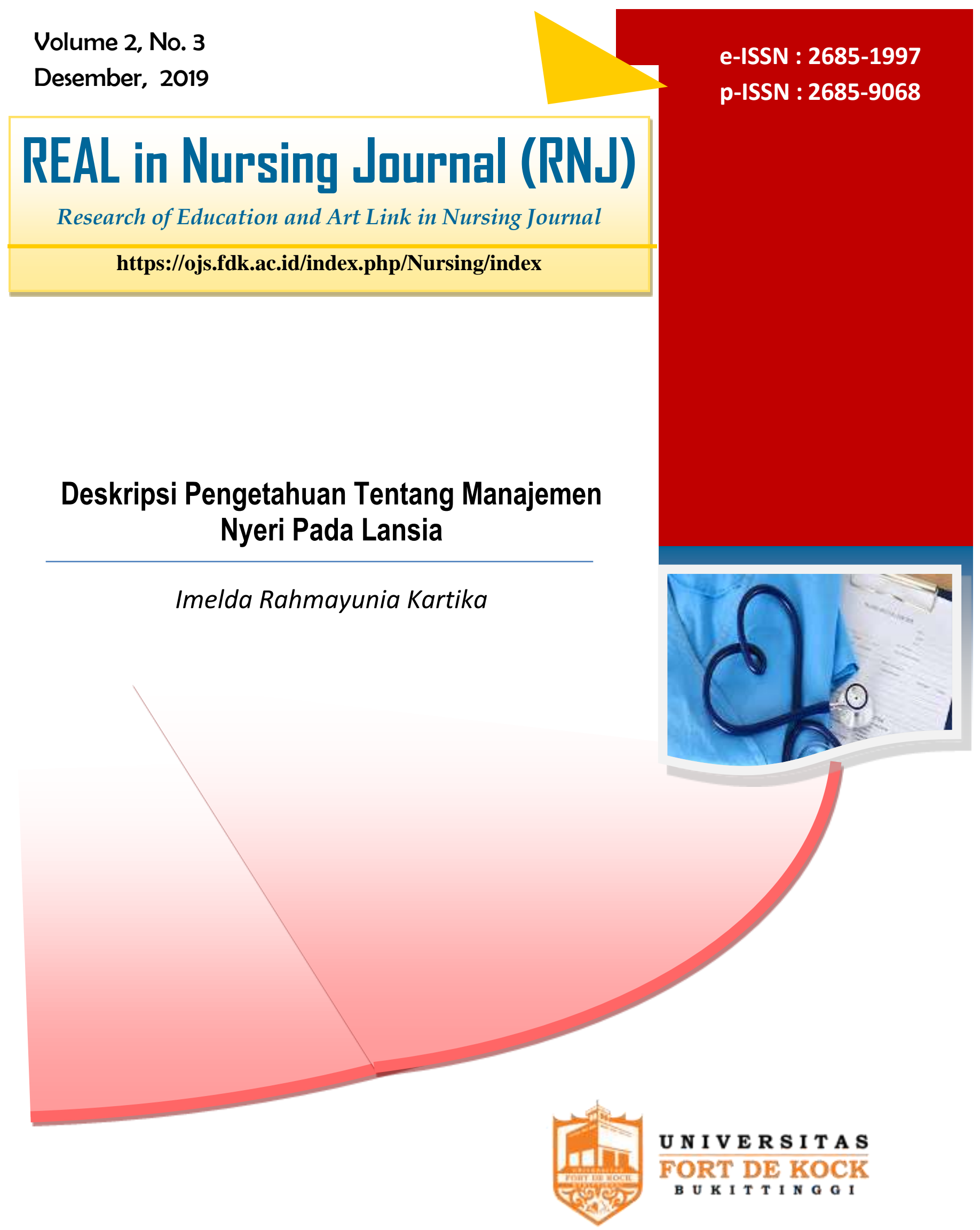

Program Studi Keperawatan dan Pendidikan Ners Universitas Fort de Kock Bukittinggi, Indonesia 


\title{
Deskripsi Pengetahuan Tentang Manajemen Nyeri Pada Lansia
}

\begin{tabular}{c} 
REAL in \\
Nursing \\
Journal (RNJ) \\
https://ojs.fdk.ac.id/inde \\
x.php/Nursing/index \\
\hline
\end{tabular}

Keywords:

Pain, Elderly, Knowledge

\section{Korespondensi:}

Imelda Rahmayunia Kartika imelda.rahmayunia@fdk. ac.id

\section{Prodi Keperawatan dan Ners, Universitas Fort De Kock Bukittinggi}

\author{
Imelda Rahmayunia Kartika
}

\begin{abstract}
The percentage of elderly people in Indonesia increases every year to reach 9.27 percent or around 24.49 million people in 2018. The health problem that often occurs in the elderly is chronic pain due to several diseases. Pain is a general picture that persists and is closely related to substantial morbidity in the elderly. This study aims to get an overview of elderly knowledge regarding pain management. Using a quantitative research design and analytical description approach, this study was conducted on 46 elderly people in the working area of the Guguak Panjang Health Center, Bukittinggi City. The elderly were given a questionnaire based on the Nursing Outcome Classification regarding Knowledge: Pain management. Data analysis used descriptive analysis to see the description of each statement point in the questionnaire. The results of this study indicate that there are still $43.5 \%$ of the elderly lacking in poor knowledge in pain management. Less knowledge influences how to deal with pain in the elderly. It is expected that the elderly will be given education about pain management so that they can improve their health status.
\end{abstract}

\begin{abstract}
ABSTRAK
Persentase lansia di Indonesia, meningkat setiap tahunnya hingga mencapai 9,27 persen atau sekitar 24,49 juta orang di tahun 2018. Masalah kesehatan yang sering terjadi pada lansia adalah nyeri kronik akibat beberapa penyakit. Nyeri adalah gambaran umum yang terus-menerus terjadi dan erat berhubungan dengan morbiditas yang substansial pada lansia. Penelitian ini bertujuan untuk mendapatkan gambaran pengetahuan lansia mengenai manajemen nyeri. Dengan menggunakan desain penelitian kuantitatif dan pendekatan deskripsi analitik, penelitian ini dilakukan pada 46 orang lansia di wilayah kerja Puskesmas Guguak Panjang, Kota Bukittinggi.. Lansia diberikan kuesioner yang diadopsi dari Nursing Outcome Classification mengenai Pengetahuan: Manajemen nyeri. Analisa data menggunakan analisa deskriptif untuk melihat gambaran setiap poin pernyataan dalam kuesioner Hasil penelitian ini menunjukkan masih terdapat $43.5 \%$ lansia kurang memiliki pengetahuan yang kurang baik dalam manajemen nyeri. Pengetahuan yang kurang pada lansia akan berpengaruh terhadap cara penanganan nyeri akibat berbagai penyakit yang dideritanya. Diharapkan lansia diberikan edukasi terhadap penanganan nyeri sehingga dapat meningkatkan derajat kesehatannya.
\end{abstract}

Kata kunci : Nyeri, Lansia, Pengetahuan 


\section{PENDAHULUAN}

Perubahan dalam tatanan demografi pada dua dekade terakhir ini, menciptakan tantangan tersendiri. Hal ini sebagai dampak dari ledakan angka kelahiran yang terjadi pada beberapa puluh tahun yang lalu. BPS (2018) memproyeksikan pada kisaran tahun 2045, Indonesia mungkin saja memiliki 63,31 juta penduduk yang lanjut usia (lansia) atau hampir sekitar 20 persen dari populasi. Bahkan, proyeksi PBB menyebutkan bahwa persentase lansia Indonesia akan mencapai 25 persen pada tahun 2050 atau sekitar 74 juta lansia. Peningkatan yang begitu pesat ini membawa konsekuensi tersendiri terhadap pembangunan nasional.

Di satu sisi, peningkatan lansia menunjukkan keberhasilan program-program terkait layanan kesehatan beserta segala turunannya yang telah dicanangkan pemerintah selama ini. Bahkan jika kondisi lansia dalam keadaan mandiri, sehat, aktif, dan produktif, secara tidak langsung juga akan berdampak pada perekonomian masyarakat dan negara ini kelak. Akan tetapi, di sisi lain, peningkatan jumlah lansia juga akan menjadi tantangan tersendiri ketika persiapan pra-lansia untuk menyambut masa senja tidak terlalu baik yang mengakibatkan lansia di masa mendatang jauh dari kata sehat, aktif, dan produktif. Hal tersebut berimplikasi terhadap berbagai aspek kehidupan, baik kesehatan, sosial, ekonomi, maupun lingkungan.

Selama kurun waktu hampir 50 tahun (19712018), persentase penduduk lansia Indonesia meningkat sekitar dua kali lipat. Pada tahun 2018, persentase lansia mencapai 9,27 persen atau sekitar 24,49 juta orang. Adapun persentase lansia di Indonesia didominasi oleh lansia muda (kelompok umur 60-69 tahun) yang persentasenya mencapai 63,39 persen, sisanya adalah lansia madya (kelompok umur 70-79 tahun) sebesar 27,92 persen, dan lansia tua (kelompok umur 80+) sebesar 8,69 persen. Pada tahun 2018 setiap 100 orang penduduk usia produktif harus menanggung 15 orang penduduk lansia.

Lansia mengalami penurunan fungsi tubuh. Rasa nyeri adalah masalah yang umum terjadi pada lansia. Survey kesehatan nasional tahun 2001 menunjukkan bahwa pada usia lebih dari 55 tahun, terdapat $40 \%$ lansia yang mengalami nyeri. Keluhan rasa nyeri yang dirasakan lansia biasanya dipengaruhi beberapa faktor dan terkadang terdapat banyak hambatan dalam penatalaksanaanya. Akibat penatalaksanaan yang kurang baik pada keluhan rasa nyeri yang dialami seseorang akan berdampak pada status kesehatan dan kualitas hidup lansia tersebut.

Sementara proses penuaan normal tidak selalu menjamin gejala nyeri kronis, orang lanjut usia jauh lebih mungkin untuk mengembangkan kondisi nyeri daripada rekan-rekan mereka yang lebih muda. Ada banyak modalitas pengobatan efektif yang tersedia sebagai intervensi terapeutik potensial untuk pasien usia lanjut, termasuk tetapi tidak terbatas pada analgesik seperti NSAID dan opioid, serta beberapa teknik intervensi nyeri (Jones et al., 2016)

Penatalaksanaan yang tidak adekuat dapat berhubungan dengan rasa depresi, isolasi hubungan social, ketidakmampuan dan dapat pula menyebabkan gangguan tidur. Nyeri terutama ditangani melalui penggunaan obatobatan (Malec \& Shega, 2015). Namun beberapa teknik nonfarmakologik dapat membantu mengendalikan nyeri seperti: masase, relaksasi dan imajinasi, stimulasi saraf dengan listrik transkutan, penggunaan kompres 
panas dan dingin, sentuhan terapeutik, meditasi, hipnotis dan akupresur, TENS (Transcutaneus Electrical Nerve stimulation) dan telah dibuktikan dalam beberapa penelitian bahwa adanya pengaruh yang signifikan penggunaan metode non farmakologik terhadap penurunan nyeri pada lansia, sehingga dengan demikian penggunaan metode nonfarmakologik dalam menurunkan nyeri pada lansia sangat disarankan digunakan dalam menurunkan nyeri pada lansia (Silverman, Catania, Azam, \& Baratta, 2018). Nyeri terus-menerus pada lansia sangat umum terjadi, dan berhubungan dengan morbiditas. Manajemen optimal dimulai dengan penilaian, termasuk nyeri, intensitas, karakteristik, dan gangguan; kondisi menyakitkan; perilaku nyeri; morbiditas terkait nyeri; perawatan nyeri; dan gaya koping. Manajemen nyeri lansia dipengaruhi bayak faktor. Pengetahuan yang cukup tentunya diperlukan dalam mengatasi rasa nyeri akibat penyakit kronis yang diderita lansia (Aisyah, 2017).

Berdasarkan beberapa penjelsan diatas, penelitian ini bertujuan untuk mendapatkan gambaran pengetahuan lansia mengenai manajemen nyeri. Saat lansia itu sendiri mengalami nyeri kronik akibat penyakit yang dideritanya, bagaimana gambaran pengetahuannya dalam menangani rasa sakit tersebut?

\section{METODE PENELITIAN \\ Desain penelitian}

Penelitian ini menggunakan desain penelitian kuantitatif dengan pendekatan deskriptif analitik dengan tujuan menganalisa hasil pengetahuan lansia tentang manajemen nyeri.

\section{Sampel penelitian}

Sampel penelitian ini adalah 46 responden di wilayah kerja Puskesmas Guguak Panjang Bukittinggi pada pertengahan November 2019. Sampel diambil menggunakan accidental sampling, dengan kriteria inklusi adalah pasien lansia dengan penyakit kronis dan mengalami nyeri.

\section{Instrumen penelitian}

Instrumen yang digunakan adalah kuesioner tentang pengetahuan: manajemen nyeri yang diambil berdasarkan instrumen penilaian Nursing Outcomes Classification yang dimodifikasi yakni berisi 15 item pernyataan positif menggunakan skala likert dengan penilaian sbb: "Tidak ada pengetahuan" dinilai 1, "Pengetahuan terbatas" dinilai 2, "Pengetahuan sedang" dinilai 3, dan "Pengetahuan banyak" dinilai 4 dan "Pengetahuan sangat banyak" dinilai 5 .

\section{Analisa data}

Analisa data yang digunakan adalah deskriptif frekuensi untuk melihat gambaran variabel pengetahuan lansia tentang manajemen nyeri.

\section{HASIL PENELITIAN}

Analisa univariat dilakukan untuk menggambarkan karakteristik variabel penelitian yang akan disajikan dalam bentuk tabel distribusi frekuensi. Pada penelitian ini analisa univariat akan menggambarkan kategori pengetahuan lansia tentang manajemen nyeri. 
Tabel 1

Distribusi Frekuensi Karakteristik dan kategori pengetahuan lansia

\begin{tabular}{|c|c|c|c|c|}
\hline No & Variabel & Mean (SD) & $f$ & $\%$ \\
\hline 1 & Usia & $61.48(7.216)$ & & \\
\hline \multirow[t]{4}{*}{2} & Status tinggal Lansia & & & \\
\hline & Tinggal Bersama & & 30 & 65.2 \\
\hline & Keluarga & & & \\
\hline & Tinggal Sendiri & & 16 & 34.8 \\
\hline \multirow[t]{6}{*}{3} & Penyakit penyerta Lansia & & & \\
\hline & Hipertensi & & 18 & 39.2 \\
\hline & Rematik & & 7 & 15.2 \\
\hline & Asam urat & & 5 & 10.8 \\
\hline & Jantung & & 6 & 13.1 \\
\hline & Gastritis & & 10 & 21.7 \\
\hline \multirow[t]{3}{*}{4} & Kategori Pengetahuan Lansia & & & \\
\hline & Kurang Baik & & 20 & 43,5 \\
\hline & Baik & & 26 & 56,5 \\
\hline
\end{tabular}

Berdasarkan tabel distribusi frekuensi 1 dapat diketahui bahwa dari 46 orang responden, tercatat rata-rata usia lansia adalah 61 tahun. Lansia lebih banyak tinggal bersama keluarga $(65.2 \%)$. Penyakit yang paling banyak diderita lansia adalah hipertensi (39.2\%), dengan kategori pengetahuan lansia mengenai manajemen nyeri adalah dalam rentang yang baik yakni $56.5 \%$ lansia.

\section{Tabel 2}

Distribusi frekuensi berdasarkan kuesioner tentang pengetahuan lansia mengenai manajemen nyeri di wilayah kerja Puskesmas Guguak Panjang Bukittinggi

\begin{tabular}{llll}
\hline Variable & a & Mean & SD \\
\hline Faktor penyebab nyeri & 8 & 2,4 & 0,829 \\
Tanda dan gejala nyeri & 6 & 3,0 & 0,631 \\
Strategi untuk mengontrol nyeri & 6 & 3,0 & 0,759 \\
Strategi untuk mengelola nyeri kronis & 7 & 2,7 & 0,640 \\
Cara Pemakaian Obat yang aman yang diresepkan & 6 & 3,0 & 0,759 \\
Efek samping obat & 5 & 3,3 & 0,971 \\
Penyimpanan obat yang benar & 2 & 3,6 & 0,774 \\
Pentingnya kepatuhan terhadap rejimen obat & 3 & 3,5 & 0,836 \\
Pentingnya menginformasikan profesional kesehatan tentang & 2 & 3,6 & 0,886 \\
obat yang dipakai saat ini & & & \\
Teknik manajamen nyeri yang tidak menggunakan obat & 3 & 3,5 & 0,937 \\
Teknik relaksasi nafas dalam & 3 & 3,5 & 0,888 \\
Manfaat teknik relaksasi & 4 & 3,4 & 0,886 \\
Teknik manajemen nyeri lain & 4 & 3,4 & 1,109 \\
Teknik pijat/massage & 2 & 3,6 & 1,105 \\
Manfaat teknik pijat/massage & 1 & 3,7 & 1,100 \\
\hline
\end{tabular}

$a=$ rangking variabel 
Berdasarkan tabel diatas, diketahui bahwa lansia sudah memiliki pengetahuan yang baik mengenai teknik manajemen nyeri non farmakologis. Manajemen nyeri non farmakologis yang paling umum dilakukan lansia adalah teknik pijat/massage. Lansia paling banyak mengetahui ini dengan mean 3,7 $(S D=1,100)$. Sementara itu, lansia menjawab paling tidak tahu mengenai faktor penyebab nyeri yang terjadi, denga mean $2,4(S D=0,892)$.

\section{PEMBAHASAN}

Perawatan pada lansia dengan rasa sakit merupakan hal yang kompleks dan dipengaruhi oleh perubahan terkait usia dalam farmakokinetik dan farmakodinamik. Nyeri kronis meliputi serangkaian komponen sensoris-diskriminatif, motivasional-afektif, dan kognitif-evaluatif yang kompleks. Karena kompleksitas ini, baik pendekatan farmakologis dan nonfarmakologis harus dipertimbangkan untuk mengobati rasa sakit/ nyeri yang dirasakan. Menurut (Dalacorte, Rigo, \& Dalacorte, 2011), terdapat hubungan sumber daya nonfarmakologis dengan pengobatan farmakologis yang dapat membantu mengurangi penggunaan analgesik dan meminimalkan efek samping dari pengobatan jangka panjang.

Penelitian menyebutkan bahwa lansia juga tahu bagaimana penyimpanan obat yang benar, dimana hal ini menunjukkan bahwa lansia juga menggunakan obat-obatan dalam hal penanganan nyeri kronis yang dideritanya. Perawatan farmakologis ditingkatkan secara teratur dari non-opioid menjadi opioid lemah menjadi opioid kuat. Obat tambahan seperti antikonvulsan dan antidepresan mungkin diperlukan bagi lansia yang merasakan nyeri (Dalacorte, Rigo, \& Dalacorte, 2011). Penggunaan analgesik secara berurutan untuk obat-obatan dan opioid dianggap efektif dan relatif murah untuk menghilangkan rasa sakit, tetapi tidak ada studi khusus yang dirancang dengan baik pada pasien lansia. Tidak ada rekomendasi khusus tentang penggunaan jangka panjang terapi komplementer dan alternatif.

Pengetahuan yang baik mengenai manajemen nyeri perlu bagi lansia. Diperkirakan nyeri muncul dari 45 persen menjadi 85 persen dari populasi geriatri. Banyak dari itu yang ditangani. Nyeri yang tidak diobati menyebabkan masalah lain, termasuk penurunan kualitas hidup, penurunan sosialisasi, depresi, gangguan tidur, gangguan kognitif, dan kekurangan gizi. Untuk populasi yang sudah rentan karena penuaan, biaya yang dikeluarkan untuk kunjungan dokter yang lebih sering dan rawat inap dapat sangat merugikan secara finansial. Para profesional kesehatan memiliki kewajiban moral untuk membantu orang tua yang sakit. Penatalaksanaan nyeri pada pasien geriatrik dapat dipersulit dengan perubahan fisiologi yang terjadi seiring bertambahnya usia (Robinson, 2007).

Berdasarkan hasiql penelitian, didapatkan bahwa lansia cenderung memiliki pngetahuan yang banyak mengenai teknik pijat dan manfaatnya untuk mengurangi nyeri. Sejumlah terapi komplementer telah ditemukan memiliki beberapa khasiat di antara populasi yang lebih tua, termasuk akupunktur, stimulasi saraf listrik transkutan (TENS) dan pijat. Pendekatan semacam itu dapat memengaruhi rasa sakit dan kecemasan. Beberapa pendekatan psikologis telah ditemukan bermanfaat bagi populasi yang lebih tua, termasuk imaginaery, nafas dalam dan relaksasi (Smith, Levett, Collins, \& Crowther, 2011). Ada juga beberapa 
bukti yang mendukung penggunaan terapi perilaku kognitif (CBT) di antara populasi panti jompo, tetapi tentu saja pendekatan ini membutuhkan pelatihan dan waktu. Ada banyak area yang memerlukan penelitian lebih lanjut, termasuk manajemen farmakologis di mana pendekatan sering diuji pada populasi yang lebih muda dan kemudian diterjemahkan secara keseluruhan. Studi prevalensi perlu konsistensi dalam hal usia, diagnosis dan terminologi, dan pekerjaan lebih lanjut perlu dilakukan untuk mengevaluasi pendekatan non-farmakologis ("Guidance on the management of pain in older people," 2013).

Orang yang lebih tua atau lansia juga lebih mungkin hidup dengan beberapa penyakit kronis, memerlukan banyak obat setiap hari, sehingga meningkatkan risiko penyakit-obat negatif dan interaksi obat-obat. Pasien yang lebih tua sering menunjukkan gejala nyeri yang tidak biasa. Depresi juga dapat berperan dalam penilaian dan perawatan nyeri (Sánchez, Martínez, Miró, \& Medina, 2011). Karena beberapa alasan, banyak orang tua memilih untuk tidak melaporkan rasa sakit yang mereka derita. Seringkali mereka takut bahwa mereka akan dirawat di rumah sakit tanpa sadar atau mengalami prosedur invasif jika mereka melaporkaannya.

Hambatan penting lainnya untuk manajemen nyeri adalah fakta bahwa orang tua sering salah informasi tentang proses penuaan, analgesik, manajemen nyeri, dan kecanduan opioid. Pengakuan masalah perawatan rasa sakit pada orang tua memicu beberapa pertanyaan seperti apa yang bisa dilakukan untuk menyelesaikan masalah nyeri yang mereka derita. Perlu adanya edukasi terkait hal ini. Sesi pendidikan yang dilakukan tenaga kesehatan terutama perawat komunitas/gerontik di Puskesmas akan meningkatkan kualitas perawatan pasien, karena mereka meningkatkan keterampilan dan sikap manajemen nyeri sebagai penyedia layanan kesehatan profesional.

Berdasarkan hasil penelitian, lansia menjawab paling tidak tahu mengenai faktor penyebab nyeri yang terjadi, denga mean $2,4(S D=0,892)$. Nyeri mungkin tidak dilaporkan karena beberapa pasien lansia salah percaya bahwa nyeri adalah proses penuaan yang normal. Penilaian rasa sakit yang komprehensif meliputi riwayat medis menyeluruh dan pemeriksaan fisik, tinjauan sistem dan hasil laboratorium terkait dan tes diagnostik. Penyedia layanan kesehatan seperti dokter, atau perawat harus memiliki pemahaman yang luas tentang perubahan farmakologis dan fisiologis yang terjadi pada populasi geriatri (Sloman, Ahern, Wright, \& Brown, 2001). Hal itu meliputi penilaian nyeri yang tepat, pemeriksaan fisik, perubahan patofisiologis pada lansia, perubahan farmakokinetik dan farmakodinamik, dan modalitas manajemen nyeri yang ada. Pendekatan multidisiplin direkomendasikan untuk menyelidiki semua opsi yang memungkinkan untuk manajemen yang optimal, termasuk farmakoterapi, prosedur intervensi, rehabilitasi fisik, dan dukungan psikologis (Kaye, Baluch, \& Scott, 2010).

\section{KESIMPULAN}

Penelitian ini menyimpulkan bahwa pendidikan lebih lanjut tentang manajemen nyeri sangat diperlukan pada pasien usia lanjut. Pendidikan pasien juga sangat penting. Ketika dikombinasikan dengan pengajaran tentang manajemen diri dan strategi koping, itu dapat meningkatkan manajemen nyeri pasien. Oleh karena itu, perawat di semua bidang perawatan, bukan hanya mereka yang bekerja di fasilitas perawatan lansia, membutuhkan 
pengetahuan yang baik tentang manajemen nyeri lansia untuk memfasilitasi perawatan keperawatan yang penuh kasih dan efektif.

\section{UCAPAN TERIMA KASIH}

Terima kasih yang seluasnya kepada seluruh responden yang bersedia mengisi kuesioner dalam penelitian ini. Selanjutnya, terima kasih banyak atas dukungan dari berbagai pihak terutama Universitas Fort De Kock dan seluruh pananggung jawab kegiatan HKN (Hari Kesehatan Nasional) dalam hal memfasilitasi penelitain ini. Generasi Sehat Indonesia Unggul.

\section{DAFTAR PUSTAKA}

Aisyah, S. (2017). Manajemen Nyeri Pada Lansia Dengan Pendekatan Non Farmakologi. Jurnal Keperawatan Muhammadiyah, 2(1). https://doi.org/10.30651/jkm.v2i1.1201

Dalacorte, R. R., Rigo, J. C., \& Dalacorte, A. (2011). Pain management in the elderly at the end of life. North American Journal of Medical Sciences. https://doi.org/10.4297/najms.2011.3348

Guidance on the management of pain in older people. (2013). Age and Ageing. https://doi.org/10.1093/ageing/afs200

Jones, M. R., Ehrhardt, K. P., Ripoll, J. G., Sharma, B., Padnos, I. W., Kaye, R. J., \& Kaye, A. D. (2016). Pain in the Elderly. Current Pain and Headache Reports. https://doi.org/10.1007/s11916-016-05512

Kaye, A. D., Baluch, A., \& Scott, J. T. (2010). Pain management in the elderly population: A review. Ochsner Journal.

Malec, M., \& Shega, J. W. (2015). Pain Management in the Elderly. Medical Clinics of North America. https://doi.org/10.1016/j.mcna.2014.11.00 7

Robinson, C. L. (2007). Relieving pain in the elderly. Health Progress (Saint Louis, Mo.).

Sánchez, A. I., Martínez, M. P., Miró, E., \& Medina, A. (2011). Predictors of the Pain Perception and Self-Efficacy for Pain Control in Patients with Fibromyalgia. The Spanish Journal of Psychology. https://doi.org/10.5209/rev_sjop.2011.v14. $\mathrm{n} 1.33$

Silverman, E., Catania, L., Azam, N., \& Baratta, J. L. (2018). Pain management. In Orthopaedic Knowledge Update 12. https://doi.org/10.7748/ns.32.3.33.s37

Sloman, R., Ahern, M., Wright, A., \& Brown, L. (2001). Nurses' knowledge of pain in the elderly. Journal of Pain and Symptom Management. https://doi.org/10.1016/S08853924(01)00248-2

Smith, C. A., Levett, K. M., Collins, C. T., \& Crowther, C. A. (2011). Relaxation techniques for pain management in labour. Cochrane Database of Systematic Reviews.

https://doi.org/10.1002/14651858.cd0095 14 